\title{
Molecular gut content analysis demonstrates that Calanus grazing on Phaeocystis pouchetii and Skeletonema marinoi is sensitive to bloom phase but not prey density
}

\author{
Jessica L. Ray ${ }^{1, *}$, Katrine S. Skaar ${ }^{1}$, Paolo Simonelli ${ }^{2}$, Aud Larsen ${ }^{1}$, Andrey Sazhin ${ }^{3}$, \\ Hans H. Jakobsen ${ }^{4}$, Jens C. Nejstgaard ${ }^{5}$, Christofer Troedsson ${ }^{1}$ \\ ${ }^{1}$ Uni Research Environment, Uni Research AS, Postboks 7810, 5020 Bergen, Norway \\ ${ }^{2}$ Department of Biology, University of Bergen, 5020 Bergen, Norway \\ ${ }^{3}$ P. P. Shirshov Institute of Oceanology, Russian Academy of Sciences, Laboratory of Ecology of Plankton Organisms, \\ Nakhimovsky Prospect 36, Moscow, Russia \\ ${ }^{4}$ Aarhus University, Bioscience, Frederiksborgvej 399, 4000 Roskilde, Denmark \\ ${ }^{5}$ Leibniz Institute of Freshwater Ecology and Inland Fisheries, Dep. 3, Experimental Limnology, Alte Fischerhütte 2, \\ 16775 Stechlin, Germany
}

\begin{abstract}
Mesozooplankton grazing selection in complex marine microbial communities is a poorly understood yet critical structuring component of marine microbial food webs. We wished to quantitatively assess how relative grazing by the calanoid copepod Calanus spp. changed as a function of prey abundance dynamics in a controlled experimental setting. Our study focused on haptophyte- (Phaeocystis pouchetii) and diatom- (Skeletonema marinoi) dominated plankton communities in a $22 \mathrm{~d}$ seawater mesocosm experiment during the spring bloom in southwestern Norway. Using quantitative PCR, we analyzed the ratios of $P$. pouchetii or $S$. marinoi abundances in copepod gut content to their abundance in mesocosm seawater as proxies for understanding relative grazing across phytoplankton bloom development. We observed low relative grazing by Calanus on P. pouchetii and S. marinoi in mesocosms during peaks in phytoplankton abundance, suggesting that Calanus grazing on these phytoplankton was both low and uncoupled from phytoplankton density. We did observe a small but signficant increase in relative grazing on S. marinoi after the demise of the diatom bloom, suggesting that senescent $S$. marinoi may be more bioavailable prey for Calanus. In conclusion, the use of qPCR ratios as proxy for relative prey consumption indicates the potential importance of phytoplankton bloom phase, but not relative prey density, for Calanus prey selection.
\end{abstract}

KEY WORDS: Calanus $\cdot$ Raunefjorden $\cdot \mathrm{qPCR} \cdot$ Copepod grazing $\cdot$ Mesocosm

\section{INTRODUCTION}

Mesozooplankton, and in particular copepods (Maxillopoda: Copepoda), rank among the most abundant metazoans in the ocean, both in terms of abundance and biomass (Nejstgaard et al. 2008), according them

${ }^{*}$ Corresponding author: jessicalouiseray@gmail.com the substantial potential to influence the vertical flow of carbon and nutrients in the marine environment (Jónasdóttir et al. 2015). Copepods readily consume large diatom chains during seasons of upwelling and seasonal diatom blooms (Fessenden \& Cowles 1994, Kiørboe \& Nielsen 1994), thereby constituting a direct

(C) Uni Research Ltd 2016. Open Access under Creative Commons by Attribution Licence. Use, distribution and reproduction are unrestricted. Authors and original publication must be credited. 
link between primary production and higher trophic levels. Due to their small size, many phytoplankton species with diameters $<5 \mu \mathrm{m}$ are not typically considered to be important food sources for copepods, which frequently exhibit prey choice based on size (Sommer et al. 2000) or swimming behavior (Kiørboe \& Visser 1999), and even chemical cues in the case of larger aggregates (Goncalves \& Kiørboe 2015). The high-latitude haptophyte Phaeocystis spp. has a unique life history in which it can alternate between single, flagellated cells of approx. $4 \mu \mathrm{m}$ diameter, to large aggregates ('colonies') containing tens of thousands of non-motile cells (reviewed in Schoemann et al. 2005) during the spring bloom. This size variation raises the possibility that Phaeocystis colonies represent an abundant and important food source for copepods during the high-latitude spring bloom season.

There are conflicting reports on the role of Phaeocystis in the copepod diet (reviewed in Schoemann et al. 2005 and Nejstgaard et al. 2007). It has been argued that colony formation by Phaeocystis is a defense mechanism against grazing (Estep et al. 1990, Gasparini et al. 2000). Estep et al. (1990) investigated grazing by $C$. finmarchicus on natural microbial assemblages dominated by different physiological stages of a $P$. pouchetii bloom and observed that copepod consumption of $P$. pouchetii colonies in bottle incubation experiments occurred only when postbloom colonies had begun to fragment. In another study of small copepods collected from the southern bight of the North Sea, Gasparini et al. (2000) were unable to detect grazing on Phaeocystis colonies when copepods were incubated with $P$. globosadominated natural microbial assemblages in bottle incubation experiments. The authors of those studies interpreted their findings as evidential of a life stagespecific defense behavior in the genus Phaeocystis, where colony formation is an anti-predation defense mechanism during bloom development (Jakobsen \& Tang 2002, but see Irigoien et al. 2005), and that only during colony senescence does Phaeocystis become available as a food source for mesozooplankton. It remains unclear whether copepods contribute to topdown control of Phaeocystis blooms in high-latitude seas, or if this top-down control is dependent upon Phaeocystis bloom development.

Analysis of copepod gut content to identify feeding behavior in situ has often relied on pigment analysis (Gifford \& Dagg 1988, Kleppel et al. 1991, Gasparini et al. 2000), but this method does not account for nonpigmented prey and is neither taxon-specific nor sensitive due to rapid degradation of pigments in the copepod gut (Nejstgaard et al. 2008). Molecular detection of prey genomic DNA in the predator gut using quantitative PCR (qPCR) allows specific and rapid detection of any organism regardless of pigment content. The short DNA regions targeted by qPCR provide the ability to quantify prey despite partial DNA digestion in the predator gut (Nejstgaard et al. 2008, Durbin et al. 2008, Simonelli et al. 2009, Troedsson et al. 2009). One type of qPCR assay, the 5'-nuclease or 'TaqMan' assay (Gibson et al. 1996), provides an additional level of prey detection specificity through the inclusion of a probe that is highly specific for the target prey organism. Moreover, multi-copy gene targets, such as the small subunit ribosomal RNA (SSU rRNA) gene, increase the detectability of target prey organisms by providing many qPCR target sequences per prey cell. Studies using qPCR to quantify prey ingestion by copepods have traditionally used the SSU rRNA gene (Troedsson et al. 2007, Nejstgaard et al. 2008, Barofsky et al. 2010, Cleary et al. 2012, Durbin et al. 2012), although other multi-copy genes have also been targeted (e.g. mtCOI; Durbin et al. 2008).

Exploiting the sensitivity and specificity of TaqMan qPCR to investigate copepod feeding, our main objective was to determine whether grazing on $P$. pouchetii by Calanus copepods changes in response to $P$. pouchetii bloom development when this phytoplankter occurs in the context of natural mixed plankton assemblages in seawater mesocosms. For comparison, we also investigated Calanus grazing on different stages of bloom development of the diatom Skeletonema spp.

\section{MATERIALS AND METHODS}

\section{Mesocosm experiment}

A seawater mesocosm experiment was conducted at the Espegrend Marine Biological Station at the University of Bergen during 8-30 March 2012. Details of the mesocosm set-up are described elsewhere (Nejstgaard et al. 2006, Stoecker et al. 2015). Briefly, reinforced transparent polyurethane mesocosm bags were attached to floating mesocosm rings (Fig. 1A) and filled in a staggered mode on 8 March 2012 (Experimental Day 0) with $11 \mathrm{~m}^{3}$ water pumped from $5 \mathrm{~m}$ depth directly adjacent to the raft. Circulation of mesocosm water was achieved using an air lift system (Jacobsen et al. 1995). Two nutrient amendments were applied to triplicate mesocosm bags on 9 March (Experimental Day 1): $16 \mu \mathrm{M}$ nitrate $+1 \mu \mathrm{M}$ phos- 


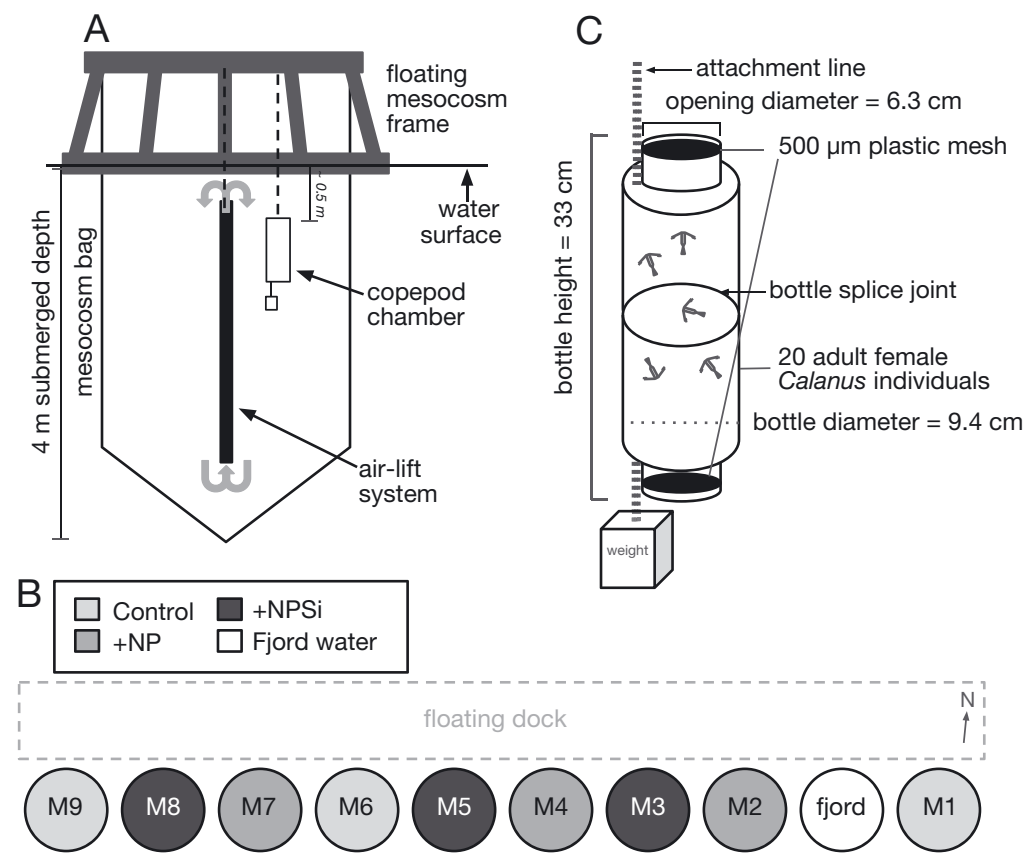

Fig. 1. Experimental setup and copepod chamber design and placement. (A) Schematic diagram of mesocosm bags in profile. (B) Mesocosm experimental set-up relative to raft orientation. Key shows treatments applied for individual mesocosm bags as denoted with ' $\mathrm{M}$ ' and bag number; mesocosm frame labelled 'fjord' indicates the location of direct water sampling and copepod chamber placement in Raunefjorden. Treatment details are given in 'Materials and methods' and in Table 1. (C) Copepod chambers used for feeding experiments

phate (NP treatment, $\mathrm{n}=3$ ) or $16 \mu \mathrm{M}$ nitrate $+1 \mu \mathrm{M}$ phosphate $+5 \mu \mathrm{M}$ silicate (NPSi treatment, $\mathrm{n}=3$ ). Three mesocosm bags were unamended with mineral nutrients and served as experimental controls (Control treatment) for nutrient amendment (Fig. 1B). For reference, 1 set of samples was also taken from surface seawater directly adjacent to the mesocosm raft at the time of sampling from the mesocosm bags ('fjord' in Fig. 1B). Water samples from all 9 mesocosms and the adjacent fjord were collected daily for chlorophyll a ( $\mathrm{chl}$ a) measurement as described in Holm-Hansen \& Riemann (1978).

\section{Copepod chambers}

Inspired by Barofsky et al. (2010), we designed flow-through copepod chambers to (1) contain copepods while (2) permitting free circulation of mesocosm water to allow copepods access to mesocosm microbiota and (3) facilitating rapid recovery and rinsing of copepods for molecular analysis. The chambers (Fig. 1C) were constructed by removing the bottom of two 11 Nalgene bottles and wedging the open bottom of one bottle into the open bottom of the other bottle until the 2 bottles overlaped by ca. $20 \mathrm{~mm}$, thus creating a spliced container with a threaded opening at both ends. A $60 \mathrm{~mm}$ diameter hole saw was used to cut out the centers of the bottle lids. Nylon netting with $500 \mu \mathrm{m}$ mesh size was then secured over the bottle openings by sandwiching the mesh between the cut bottle lids and the bottle ends. Chambers were deployed in vertical orientation in mesocosms using strings attached to a bar across the mesocosm floating frames (Fig. 1A) and attaching weights $(50 \mathrm{ml}$ Falcon tube containing gravel) to the bottom opening of each chamber (Fig. 1C).

\section{Copepod collection and sorting}

Mesozooplankton were collected from Raunefjorden ( $\left.60^{\circ} 16^{\prime} 18^{\prime \prime} \mathrm{N}, 5^{\circ} 10^{\prime} 26^{\prime \prime} \mathrm{E}\right)$ during March 2012 using a WPII plankton net with $100 \mu \mathrm{m}$ mesh size and fitted with a cod end. Plankton nets were towed obliquely from $25 \mathrm{~m}$ to $10 \mathrm{~m}$, then raised vertically from $10 \mathrm{~m}$ to surface, while vessel speed was maintained at 1 knot. Cod-end contents were gently diluted into buckets containing surface seawater (approx. temperature $4-8^{\circ} \mathrm{C}$ ) and kept in the shade during transport to land. Buckets containing collected mesozooplankton were kept at $8^{\circ} \mathrm{C}$ during sorting in the laboratory. Twenty active and physically undamaged individuals of adult Calanus spp. females (or CV juveniles when insufficient females were available) were pipette-sorted into each copepod chamber (Fig. 1C) standing in a 11 beaker containing $0.2 \mu \mathrm{m}$-filtered seawater $\left(8^{\circ} \mathrm{C}\right)$. Chambers containing copepods were then closed with $500 \mu \mathrm{m}$ plastic mesh and incubated in the dark at $8^{\circ} \mathrm{C}$ overnight before being transferred to the mesocosms early the following day. Three replicate copepod chambers were mounted in each mesocosm approx. $0.5 \mathrm{~m}$ beneath the water surface (Fig. 1A).

\section{Seawater sampling}

Seawater samples from mesocosms and Raunefjorden were collected daily between 07:00 and 08:00 h and kept at $8{ }^{\circ} \mathrm{C}$ in the dark. Microscopy and FlowCAM analysis were performed daily, while qPCR 
analysis of seawater and mesocosmincubated copepods was performed for samples collected on 11, 14, 17, 21, 24, 28 and 30 March 2012 only. The Control mesocosm M6 (Fig. 1B) developed a leak, and due to extensive volume loss was excluded from the sample collection after 21 March 2012.

\section{Microscopic and FlowCAM analysis of microeukaryotes in seawater}

Sampling for microscopic analysis was performed daily for 1 mesocosm per treatment (M1, Control; M2, NP; and M3, NPSi) as described previously (Calbet et al. 2014). Additionally, $P$. pouchetii, $S$, marinoi, ciliates and the heterotrophic dinoflagellate Gyrodinium cf. spirale were counted daily in all mesocosms using a FlowCAM II (Fluid Imagine Technologies, Scarborough, ME). Detailed descriptions of microscopy and FlowCAM methods and instrument settings can be found in the Supplement at www. int-res.com/articles/suppl/m542p063 _supp.pdf.

\section{Molecular analysis using qPCR}

Seawater samples for qPCR analysis were collected from all mesocosms and Raunefjorden in separate oncerinsed 21 bottles, and transported back to the laboratory for immediate filtration. Triplicate samples of $50-200 \mathrm{ml}$ seawater were vacuumfiltered onto $25 \mathrm{~mm}$ diameter $0.2 \mu \mathrm{m}$ pore size SUPOR filters (Pall). The volume of seawater used for filtration was reduced from $200 \mathrm{ml}$ at the start of the experiment down to $50 \mathrm{ml}$ in the NP and NPSi mesocosm treatments at the end of the experiment in order to reduce filter clogging by $P$. pouchetii colonies. However, this was corrected for in the analysis. Filters were transfered to $2.0 \mathrm{ml}$ microcentrifuge tubes containing $280 \mu \mathrm{l} 56^{\circ} \mathrm{C}$ ATL buffer (modified from the recommended $180 \mu \mathrm{l}$ in the manufacturer's protocol) and $20 \mu$ l Proteinase $\mathrm{K}$ and tubes were inverted several times to coat filters completely with lysis solution. Filters were incubated at $56^{\circ} \mathrm{C}$
Table 1. Summary of samples taken for molecular analysis during the seaStation at Espegrend in March 2012. Treatments - Control: seawater without water sampled from fjord surface directly adjacent to mesocosm raft, copepods incubated in surface water directly adjacent to raft. Volume filtered: volume of seawater filtered for molecular analysis, with 3 replicate filters per mesocosm viduals per mesocosm harvested for molecular gut content analysis

\begin{tabular}{|c|c|c|c|c|c|c|}
\hline Sample ID & $\begin{array}{c}\text { Date in } \\
\text { March } \\
2012\end{array}$ & $\begin{array}{c}\text { Experi- } \\
\text { mental } \\
\text { day }\end{array}$ & $\begin{array}{l}\text { Meso- } \\
\text { cosms }\end{array}$ & $\begin{array}{l}\text { Treat- } \\
\text { ment }\end{array}$ & $\begin{array}{l}\text { Volume } \\
\text { filtered } \\
(\mathrm{ml})\end{array}$ & $\begin{array}{c}\text { No. of } \\
\text { Cala- } \\
\text { nus }\end{array}$ \\
\hline Control11 & 11 & 3 & M1, M6 & Control & 200 & 15 \\
\hline Control14 & 14 & 6 & M1, M6, M9 & Control & 200 & 15 \\
\hline Control17 & 17 & 9 & M1, M6, M9 & Control & 200 & 15 \\
\hline Control21 & 21 & 13 & M1, M6, M9 & Control & 200 & 15 \\
\hline Control24 & 24 & 16 & M1, M9 & Control & 200 & 15 \\
\hline Control28 & 28 & 20 & M1, M9 & Control & 200,100 & 15 \\
\hline Control30 & 30 & 22 & M1, M9 & Control & 100,50 & 15 \\
\hline NP11 & 11 & 3 & $\mathrm{M} 2, \mathrm{M} 4$ & +NP & 200 & 15 \\
\hline NP14 & 14 & 6 & $\mathrm{M} 2, \mathrm{M} 4, \mathrm{M} 7$ & $+\mathrm{NP}$ & 200 & 15 \\
\hline NP17 & 17 & 9 & $\mathrm{M} 2, \mathrm{M} 4, \mathrm{M} 7$ & $+\mathrm{NP}$ & 200 & 15 \\
\hline NP21 & 21 & 13 & $\mathrm{M} 2, \mathrm{M} 4, \mathrm{M} 7$ & $+\mathrm{NP}$ & 200 & 15 \\
\hline NP24 & 24 & 16 & M2, M4, M7 & $+\mathrm{NP}$ & 200 & 15 \\
\hline NP28 & 28 & 20 & $\mathrm{M} 2, \mathrm{M} 4, \mathrm{M} 7$ & $+\mathrm{NP}$ & 100 & 15 \\
\hline NP30 & 30 & 22 & $\mathrm{M} 2, \mathrm{M} 4, \mathrm{M} 7$ & $+\mathrm{NP}$ & 50 & 15 \\
\hline NPSi11 & 11 & 3 & M3, M5 & $+\mathrm{NPSi}$ & 200 & 15 \\
\hline NPSi14 & 14 & 6 & M3, M5, M8 & $+\mathrm{NPSi}$ & 200 & 15 \\
\hline NPSi17 & 17 & 9 & M3, M5, M8 & $+\mathrm{NPSi}$ & 200 & 15 \\
\hline NPSi21 & 21 & 13 & M3, M5, M8 & $+\mathrm{NPSi}$ & 200 & 15 \\
\hline NPSi24 & 24 & 16 & M3, M5, M8 & $+\mathrm{NPSi}$ & 200 & 15 \\
\hline NPSi28 & 28 & 20 & M3, M5, M8 & $+\mathrm{NPSi}$ & 100 & 15 \\
\hline NPSi30 & 30 & 22 & M3, M5, M8 & +NPSi & $100,50,50$ & 15 \\
\hline Raunefjord11 & 11 & 3 & Raft & None & 200 & 15 \\
\hline Raunefjord17 & 14 & 6 & Raft & None & 200 & 15 \\
\hline Raunefjord17 & 17 & 9 & Raft & None & 200 & 15 \\
\hline Raunefjord21 & 21 & 13 & Raft & None & 200 & 15 \\
\hline Raunefjord24 & 24 & 16 & Raft & None & 200 & 15 \\
\hline Raunefjord28 & 28 & 20 & Raft & None & 100 & 15 \\
\hline Raunefjord30 & 30 & 22 & Raft & None & 50 & 15 \\
\hline
\end{tabular}

overnight for lysis and protein digestion, then flashfrozen in liquid nitrogen and stored at $-80^{\circ} \mathrm{C}$. A summary of all samples taken for molecular analysis is given in Table 1.

After approximately $24 \mathrm{~h}$ incubations in mesocosms, copepod chambers were removed from mesocosms one at a time. Copepods collected on the bottom plastic mesh were rinsed by dipping chambers vertically into 3 consecutive 11 beakers containing ultra-filtered seawater, prior to final immersion in anaesthetic seawater solution containing $0.37 \mathrm{mg} \mathrm{ml}^{-1}$ ethyl 3-aminobenzoate methanesulfonate (MS222) (Sigma-Aldrich). Copepod recovery from mesocosm incubations commenced at the start of the day period (approx. 08:00 h) on sampling days, and copepod 
sampling was always completed within $3 \mathrm{~h}$ after the start of sampling. Using a dissecting microscope and precision forceps, a pool of 5 copepod individuals was sorted from the anaesthetic solution into a $1.5 \mathrm{ml}$ microcentrifuge tube containing $180 \mu \mathrm{l}$ of $56^{\circ} \mathrm{C}$ lysis buffer (Buffer ATL, QIAGEN DNeasy Blood \& Tissue kit) and $20 \mu$ l Proteinase K (QIAGEN kit, $20 \mathrm{mg} \mathrm{ml}^{-1}$ ). Samples were immediately mixed by inversion then placed in a $56^{\circ} \mathrm{C}$ heat block for tissue lysis and protein digestion overnight. Lysed samples were flashfrozen in liquid nitrogen and stored at $-80^{\circ} \mathrm{C}$ until DNA extraction. Visual inspection of copepods upon recovery from mesocosm incubations confirmed that copepods had gut content and appeared to be healthy. Dead copepods, albeit rare, were occasionally recovered from chambers but were never sampled for molecular analysis.

\section{DNA extraction}

All DNA extractions were performed using the DNeasy Blood \& Tissue kit (QIAGEN). Samples frozen in ATL buffer and Proteinase $\mathrm{K}$ were thawed on ice, heated briefly at $56^{\circ} \mathrm{C}$, then vortexed for $2-3 \mathrm{~s}$ to re-dissolve precipitates in the lysis buffer. For seawater samples, filters were removed from tubes using a sterile pipette tip and discarded. Four microliters RNAse A (20 mg ml${ }^{-1}$, QIAGEN kit) was added to each sample, after which samples were incubated at room temperature (RT) for 2 min then vortexed vigorously for $15 \mathrm{~s}$. After RNAse digestion, $400 \mu \mathrm{l}$ of a 1:1 solution of AL buffer (QIAGEN kit) and 96\% ethanol were added to all samples and mixed by vortexing. Binding of DNA to filter columns and sub- sequent column washes were performed according to the manufacturer's protocol. Elution was performed with $2 \times 100 \mu \mathrm{l} 56^{\circ} \mathrm{C}$ Elution Buffer (QIAGEN kit). Samples were divided into 3 aliquots and stored at $-20^{\circ} \mathrm{C}$ until analysis. This DNA extraction method was chosen based on previous studies demonstrating high DNA extraction efficiency and reproducibility using sample types similar to those collected in this study (Nejstgaard et al. 2008, Simonelli et al. 2009).

\section{TaqMan detection of Phaeocystis pouchetii and Skeletonema marinoi}

All primer and probe information can be found in Table 2. Primer and probe candidates (see Supplement) were tested for thermodynamic properties using the IDT OligoAnalyer tool (http://eu.idtdna. com/calc/analyzer) and for target specificity using TestProbe and TestPrime on the Silva website (www. arb-silva.de). Primers Ppo-18S-Q-F1/Ppo-18S-Q-R1 amplify a $78 \mathrm{bp}$ fragment in the V4 hypervariable region of the $P$. pouchetii SSU rRNA gene. The $P$. pouchetii-specific sense strand probe Ppo-q18SprobeC is located 4 nucleotides downstream of the Ppo-18S-Q-F1. The TaqMan assay for $S$. marinoi consists of primers Skel-175Fmod and Skel-244Rmod and the sense strand $S$. marinoi-specific probe KLEM-probeF located immediately downstream of the Skel-175F primer. This assay amplifies a $69 \mathrm{bp}$ fragment in the V2 hypervariable region of the $S$. marinoi/S. costatum SSU rRNA gene. Both probes were dual-labelled with the fluorescent reporter dye 6-carboxyfluorescein (6-FAM) at their 5'-end and with the Black Hole Quencher-1 (BHQ1) at their 3'-end

Table 2. Primers and probes used in this study. 6-FAM: 6-carboxyfluorescein; BHQ1: Black Hole Quencher-1; $T_{\text {an }}$ : annealing temperature used for qPCR; position: approximate nucleotide positions based on full-length eukaryotic SSU sequences for primers and probes designed in this study

\begin{tabular}{|c|c|c|c|c|c|}
\hline Name & Sequence $\left(5^{\prime}-3^{\prime}\right)$ & $\begin{array}{c}\text { Amplicon } \\
\text { size (bp) }\end{array}$ & $\begin{array}{l}T_{\text {an }} \\
\left({ }^{\circ} \mathrm{C}\right)\end{array}$ & Position & Reference \\
\hline \multicolumn{6}{|c|}{ Full-length eukaryotic SSU rRNA gene target for cloning } \\
\hline UnivF-15 & CTGCCAGTAGTCATATGC & \multirow[t]{2}{*}{$\sim 1750$} & \multirow[t]{2}{*}{50} & $15-32$ & Frischer et al. (2000) \\
\hline UnivR-1765S & ACCTTGTTACGACTT & & & $1765-1751$ & Frischer et al. (2000) \\
\hline \multicolumn{6}{|c|}{ P. pouchetii-specific V4 SSU rRNA for 5 '-nuclease qPCR assay } \\
\hline 18S-Ppo-Q-F1 & ACTTTGAAAAAATCAGAGTG & \multirow[t]{3}{*}{78} & \multirow[t]{3}{*}{56} & $776-795$ & This study \\
\hline 18S-Ppo-Q-R1 & AGAGTCCTATTAAATTATCCC & & & $853-833$ & This study \\
\hline Ppo-q18S-probeC & [6-FAM]CTAGCAGGCAGCTCGCTCTTG[BHQ1] & & & $799-819$ & This study \\
\hline \multicolumn{6}{|c|}{ Skeletonema-specific V2 SSU rRNA for 5 '-nuclease qPCR assay } \\
\hline Skel-175Fmod & CCGCCGTGTTTATTAGTATT & \multirow[t]{3}{*}{69} & \multirow[t]{3}{*}{55.8} & $175-194$ & Barofsky et al. (2010) \\
\hline Skel-244Rmod & CAATTCGAAAGGTTATTATGACT & & & $244-222$ & Barofsky et al. (2010) \\
\hline KLEM-probeF & [6-FAM]AAACCTTCACTCTTCGGAGTTGATTTC & & & $195-211$ & This study \\
\hline
\end{tabular}




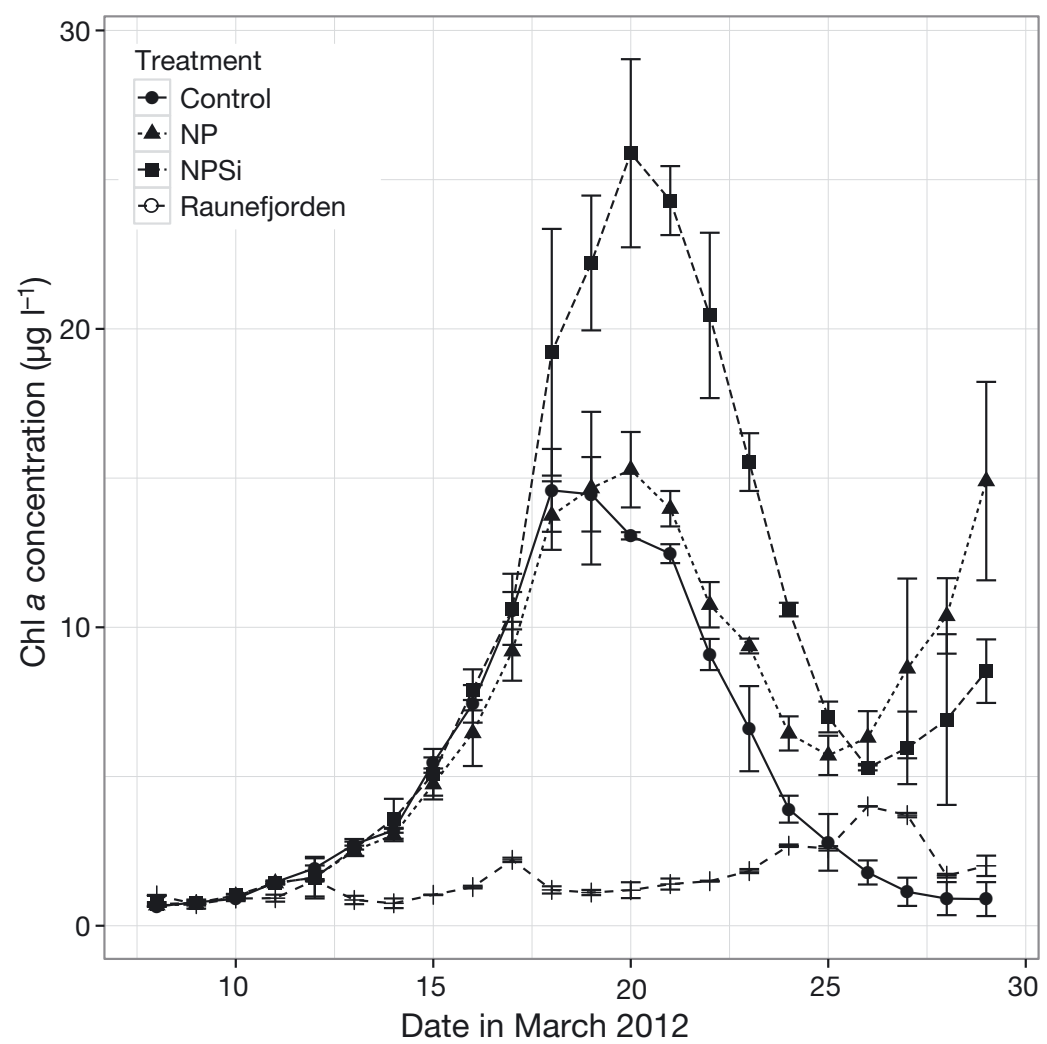

Fig. 2. Chlorophyll a concentration in all mesocosm bags and the adjacent Raunefjorden. Error bars show 95\% confidence intervals for triplicate measurements.

and were purchased HPLC-purified from SigmaAldrich. Assays were run on a CFX96 Real-Time System (Bio-Rad) in $20 \mu \mathrm{l}$ reactions prepared with SsoFast ( $P$. pouchetii) or SsoAdvanced (S. marinoi) Universal Probes Supermix (Bio-Rad). P. pouchetii detection reactions contained $1 \times$ supermix, $900 \mathrm{nM}$ each primer, $250 \mathrm{nM}$ probe, and $4 \mu \mathrm{l}$ template and were run with the program $98^{\circ} \mathrm{C}$ for $2 \mathrm{~min}$, then 40 cycles of $95^{\circ} \mathrm{C}$ for $10 \mathrm{~s}$ and $56^{\circ} \mathrm{C}$ for $5 \mathrm{~s}$, followed by plate read. $S$. marinoi qPCR reactions contained $1 \times$ supermix, $250 \mathrm{nM}$ of each primer and probe and $4 \mu \mathrm{l}$ template and were run with the program $95^{\circ} \mathrm{C}$ for $3 \mathrm{~min}$, then $40 \mathrm{cycles}$ of $95^{\circ} \mathrm{C}$ for $10 \mathrm{~s}$ and $55.8^{\circ} \mathrm{C}$ for $10 \mathrm{~s}$, followed by plate read. qPCR results for $P$. pouchetii or $S$. marinoi SSU rRNA were normalized to gene copies copepod ${ }^{-1}$ or gene copies $\mathrm{ml}^{-1}$ for copepod gut content and seawater samples, respectively.

\section{Statistical analysis}

All statistical analyses and data visualizations were conducted using the R statistical computing environment ( $\mathrm{R}$ Core Team 2015). qPCR results of cycle threshold $\left(\mathrm{C}_{\mathrm{T}}\right)$ values $>40$ cycles (i.e. not detected) for $P$. pouchetii and $S$. marinoi in some copepod samples were manually changed to SSU rRNA gene copy number $=1$ in order to allow inclusion of these data points in statistical calculations. Ratios from qPCR analysis (ratio = gene copies copepod $^{-1}$ / gene copies $\mathrm{ml}^{-1}$ ) were tested for significant changes over time using the posthoc.kruskal.nemenyi. test function in the PMCMR package (Pohlert 2015). The R packages base and ggplot2 (Wickham 2009) were used for data visualization.

\section{RESULTS}

\section{Chlorophyll a dynamics}

Chl a measurements (Fig. 2) indicated that 2 phytoplankton blooms occurred during the mesocosm experiment. The first bloom, or exponential increase in phytoplankton growth, was delimited by a chl a maximum on 19-21 March in all 3 mesocosm treatments (Control, NP and NPSi). During this bloom period, a chl a maximum of $25 \mu \mathrm{g} \mathrm{chl} \mathrm{a} \mathrm{^{-1 }}$ was observed in the NPSi treatment, while peak chl a concentrations in the NP and Control mesocosm treatments were approx. $15 \mu \mathrm{g} \mathrm{l}^{-1}$. A subsequent phytoplankton bloom became evident as a second chl a increase on 28-30 March in the NP and NPSi mesocosm treatments. This second bloom period reached chl a concentrations of $12 \mu \mathrm{g} \mathrm{l}^{-1}$ in the NP treatment and $6 \mu \mathrm{g} \mathrm{l}^{-1}$ in the NPSi treatment. Chl a concentrations in Raunefjorden were always $\leq 3 \mu \mathrm{g} \mathrm{l} \mathrm{l}^{-1}$, although 2 weak increases in chl $a$ were observed on 17 March and on 26-27 March (Fig. 2, open symbols).

\section{Quantification of Phaeocystis pouchetii in seawater}

Microscopy (Fig. 3A) and FlowCAM (Fig. 3B) analysis of mesocosm seawater confirmed that the increasing chl a concentration toward the end of the mesocosm experiment (Fig. 2) was due to P. pouchetii blooms in the NP and NPSi mesocosm treatments. The strongest $P$. pouchetii increase was observed in the NP treatment, with peak abundances of approx. $10^{5}$ cells $\mathrm{ml}^{-1}$ as measured by both microscopy and 
Phaeocystis pouchetii

A

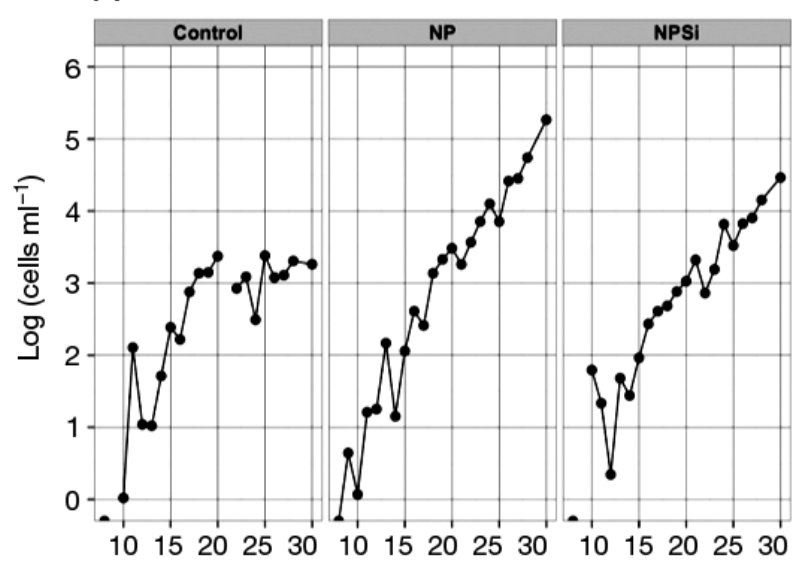

Skeletonema marinoi

Microscopy

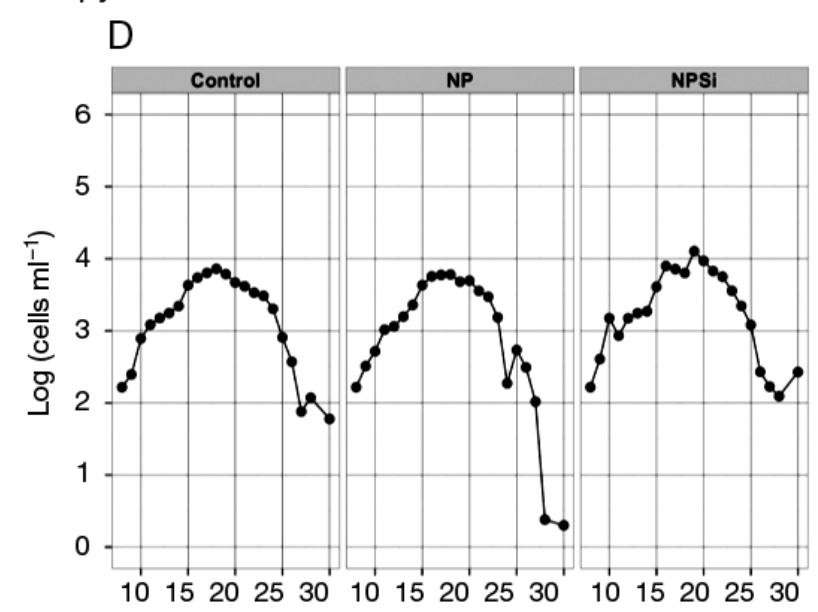

FlowCAM

B

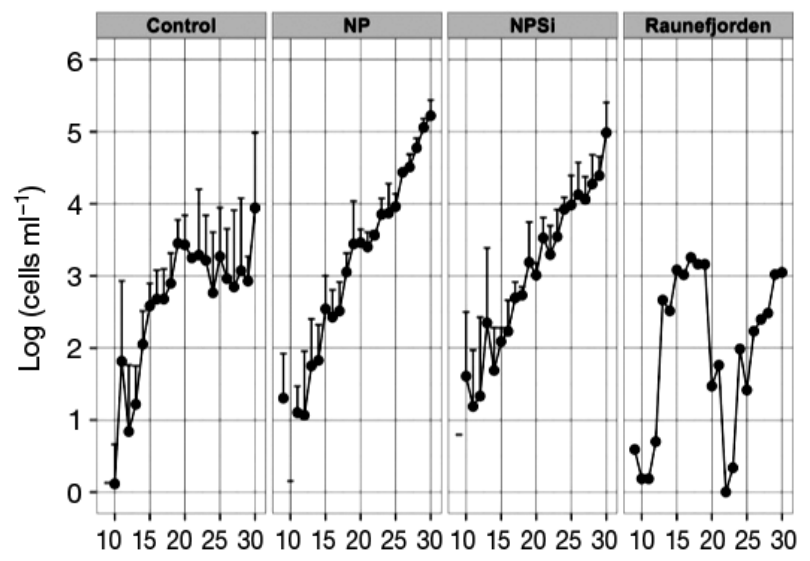

C

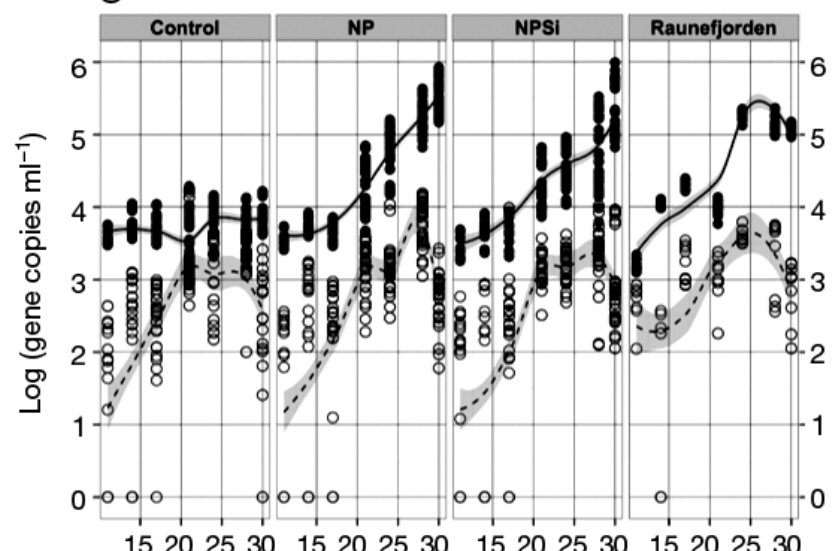

E

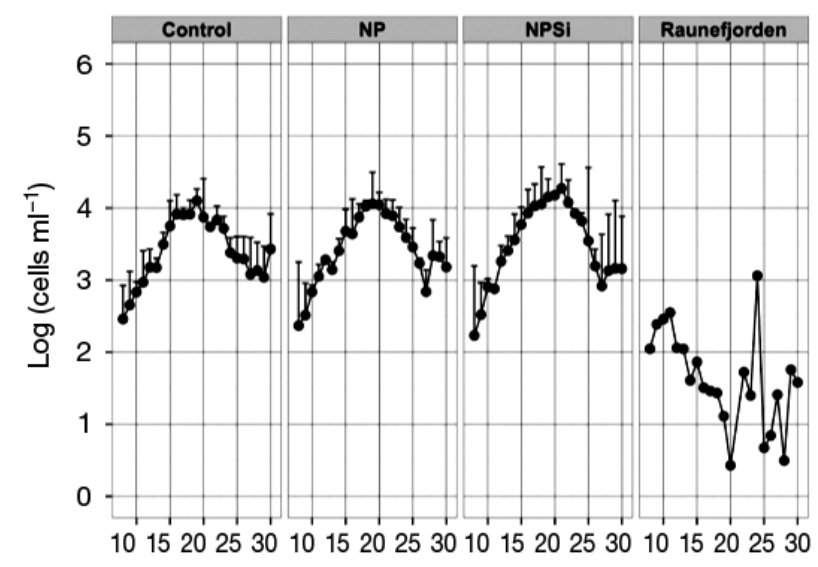

qPCR

$\mathrm{F}$

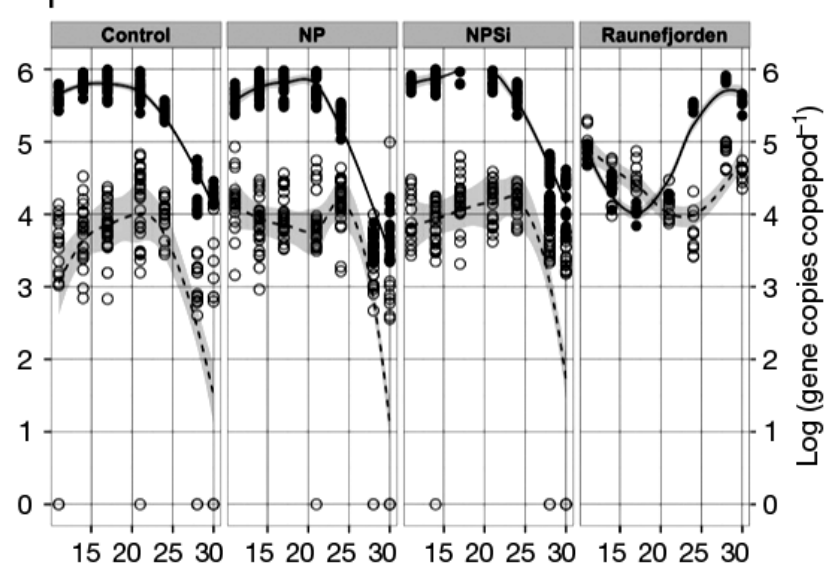

Date in March 2012

Fig. 3. Quantification results for (A-C) Phaeocystis pouchetii and (D-F) Skeletonema marinoi during March 2012. The y-axis units for qPCR results (C,F) are gene copies $\mathrm{ml}^{-1}$ (black circles and solid trendline) or gene copies copepod ${ }^{-1}$ (open circles and dashed trendline). Error bars for $(B, E)$ show standard deviation from the mean ( $\mathrm{n}=2$ or 3 replicates). Trendlines for $(\mathrm{C}, \mathrm{F})$ were calculated using the loess smoothing function, with grey zones indicating $95 \%$ confidence intervals 
FlowCAM analysis (Fig. 3A,B). P. pouchetii comprised $>80 \%$ of microeukaryotes present in the NP samples at the time of peak abundance (Fig. S1A in the Supplement). Slightly lower P. pouchetii peak density (Fig. 3A,B) and relative abundance (Fig. S1A) were observed in the NPSi mesocosm treatment, with observed peak densities of $\sim 2 \times 10^{4}$ cells ml $^{-1}$ by microscopy (Fig. 3A) or $\sim 10^{5}$ cells ml ${ }^{-1}$ by FlowCAM (Fig. 3B) measurement. For the Control mesocosms, both microscopy (Fig. 3A) and FlowCAM analysis (Fig. 3B) detected an increase in colonial $P$. pouchetii cells from 9 March until 20 March, at which time the $P$. pouchetii abundance stabilized at approx. $10^{3}$ cells $\mathrm{ml}^{-1}$. This low $P$. pouchetii abundance plateau in Control mesocosms is in accord with stably low chl a concentration in these mesocosms during the latter half of the experiment (Fig. 2). Comparison of $P$. pouchetii qPCR results with microscopy or FlowCAM counts for P. pouchetii cells shows linear relationships between microscopic and molecular methods, with variable degrees of fit (Fig. S2 in the Supplement).

$P$. pouchetii abundance in seawater as measured by qPCR was determined to be $\sim 5 \times 10^{3}$ copies $\mathrm{ml}^{-1}$ on 11 March for all treatments and Raunefjorden (Fig. 3C). Thereafter, P. pouchetii target gene copies in seawater increased exponentially in the NP and NPSi mesocosm treatments after $17 \mathrm{March}$, and after 21 March in Raunefjorden (Fig. 3C). P. pouchetii target gene copies peaked at approx. 1-2 × $10^{5}$ copies $\mathrm{ml}^{-1}$ on 30 March in the NP and NPSi mesocosm treatments (Fig. 3C), while in Raunefjorden the target gene copy number peaked at $10^{5}$ copies $\mathrm{ml}^{-1}$ on 24 March (Fig. 3C). The Control was characterized by stable $P$. pouchetii target gene counts of approximately $5 \times 10^{3}$ gene copies $\mathrm{ml}^{-1}$ throughout the experimental period (Fig. 3C), in contrast to the approx. 100 -fold increases in cell counts as measured by microscopy (Fig. 3A) or FlowCAM (Fig. 3B). In the $\mathrm{NP}$ and NPSi mesocosm treatments, peak $P$. pouchetii target gene copy abundances (Fig. 3C) in general corresponded to peak cell abundances measured by microscopy (Fig. 3A) and FlowCAM (Fig. 3B), whereas in the Control they were slightly higher than peak cell abundances determined by microscopy (Fig. 3A). FlowCAM analysis of seawater from Raunefjorden (Fig. 3B) showed a bimodal growth dynamic for $P$. pouchetii characterized by 2 apparent growth peaks interspersed by a sharp decline, although qPCR analysis of Raunefjorden seawater indicated an increase in $P$. pouchetii target gene copies up to 24 March when numbers stabilized (Fig. 3C).

\section{Quantification of Skeletonema marinoi in seawater}

Microscopy (Fig. 3D) and FlowCAM analysis (Fig. 3E) over the course of the experiment confirmed that the first peaks in chl a observed around 19-21 March in the Control, NP and NPSi mesocosm treatments (Fig. 2) was attributed to the chain-forming diatom $S$. marinoi. At peak abundance, S. marinoi reached densities of approx $10^{4}$ cells ml $^{-1}$ (Fig. 3D) and accounted for $35-50 \%$ of the total microeukaryote abundance as determined by microscopy (Fig. S1B). FlowCAM analysis identified similar trends in $S$. marinoi abundance when $S$. marinoi quantification results from all mesocosms for each treatment were averaged (Fig. 3E), demonstrating reproducible trends in $S$. marinoi dynamics in replicate mesocosms. S. marinoi in the adjacent Raunefjorden occurred at densities of $10^{1}$ to $10^{2}$ cells ml $^{-1}$ during the experimental period, but with no clear indication of bloom-like exponential growth. FlowCAM counts from Raunefjorden show general low abundances of $S$. marinoi and confirmed that no $S$. marinoi bloom development occurred at any time during the experiment.

Using qPCR to quantify $S$. marinoi in seawater (Fig. 3F), we observed slightly different trends in $S$. marinoi growth in mesocosms when compared with growth dynamics measured using microscopy (Fig. 3D) or FlowCAM (Fig. 3E) analysis. Specifically, qPCR demonstrated that $S$. marinoi in the NPSi mesocosm treatment peaked at approx. $10^{6}$ target gene copies $\mathrm{ml}^{-1}$ (Fig. 3F), whereas peak cell abundances of $S$. marinoi measured by microscopy (Fig. 3D) or FlowCAM analysis (Fig. 3E) were about $10^{4}$ cells ml ${ }^{-1}$ in the NPSi treatment. This relative quantification difference (Fig. S2), which is apparent for all 3 mesocosm treatments, is likely due to the multicopy nature of the $S$. marinoi SSU rRNA gene locus, which is present in approximately 70 copies per cellular genome (A.-L. Godhe, Univ. of Gothenburg, pers. comm.). Microscopy and FlowCAM analysis, in contrast, quantify individual cells. Incidentally, we did not observe a similar magnitude discrepancy in $P$. pouchetii target gene abundances from qPCR analysis with $P$. pouchetii cellular abundances as measured by microscopy and FlowCAM analysis (Fig. 3A-C). S. marinoi abundances in the Control, NP and NPSi mesocosms peaked at just under $10^{6}$ target gene copies $\mathrm{ml}^{-1}$ on 21 March, then decreased rapidly to approx. $10^{4}$ gene copies $\mathrm{ml}^{-1}$ by 30 March (Fig. 3), at which abundance they remained until the end of the experiment. All 3 quantification methods 
showed that the highest peak in S. marinoi abundance occurred in the NPSi mesocosm treatment (Fig. 3D-F). In Raunefjorden, qPCR detection of $S$. marinoi identified an initial decline in $S$. marinoi target gene copies, from $5 \times 10^{4}$ gene copies $\mathrm{ml}^{-1}$ on 11 March to $1 \times 10^{4}$ gene copies $\mathrm{ml}^{-1}$ on 17 March (Fig. 3F). After 17 March, however, S. marinoi gene copy numbers in Raunefjorden increased to over $10^{5}$ gene copies $\mathrm{ml}^{-1}$ by the end of the experiment. The dynamic ranges of $S$. marinoi in Raunefjorden as measured by FlowCAM (Fig. 3E) or qPCR (Fig. 3F) were similarly compact (approximately one order of magnitude), which would corroborate chl a measurements (Fig. 2) showing no large increases in autotroph (phytoplankton) growth during the experimental period.

\section{Copepod gut content analysis}

qPCR analysis of copepod samples revealed a trend of increasing $P$. pouchetii target gene copies in the copepod gut in the Control, NP and NPSi mesocosm treatments, with copy numbers ranging from approx 100-500 copies copepod ${ }^{-1}$ on 11 March to $1-2 \times 10^{3}$ copies copepod $^{-1}$ on 28 March (Fig. 3C). In samples from copepods that had been incubated in Raunefjorden, we observed an initial increase in $P$. pouchetii, from $\sim 200$ gene copies copepod $^{-1}$ on 11 March to $\sim 5 \times 10^{3}$ gene copies copepod $^{-1}$ on 24 March (Fig. 3C). Subsequently, $P$. pouchetii in Raunefjorden-incubated copepods decreased to $\sim 500$ gene copies copepod ${ }^{-1}$ by 30 March. From qPCR analysis of $S$. marinoi in copepod samples (Fig. 3F), we observed different trends in $S$. marinoi signals over time. In the Control, the number of $S$. marinoi target gene copies started at $\sim 10^{3}$ copies copepod ${ }^{-1}$ on 11 March, increased to $\sim 10^{4}$ copies copepod ${ }^{-1}$ around the time of the $S$. marinoi bloom peak around 21 March, then decreased until the end of the experiment. For copepods incubated overnight in the NP and NPSi mesocosms, however, we observed higher initial $S$. marinoi target gene copy numbers, approx. $10^{3}$ copies copepod ${ }^{-1}$, until 24 March, after which $S$. marinoi signal in copepod samples decreased similar to the Control (Fig. 3F). For Raunefjorden copepod samples, we observed an initial decline in target gene copy numbers from approx. $10^{5}$ copepod $^{-1}$ on 11 March to $10^{4}$ copepod $^{-1}$ on 24 March. After 24 March, S. marinoi qPCR signal in Raunefjorden copepod samples increased to approx. $3 \times 10^{4}$ copepod $^{-1}$ (Fig. 3F).

\section{qPCR ratios as proxies for relative grazing by Calanus}

In order to obtain a measure for grazing activity by Calanus on either P. pouchetii (Fig. 4A) or $S$. marinoi (Fig. 4B) relative to specific phytoplankton densities in seawater, we calculated the pairwise ratios of individual qPCR signals in copepod samples (normalized to copies copepod ${ }^{-1}$ ) to individual qPCR signals in seawater (normalized to copies $\mathrm{ml}^{-1}$ ) at the time of recovery of copepods from overnight mesocosm incubations. Individual mesocosm treatments and Raunefjorden were tested for a significant effect on sampling date on qPCR ratios using Kruskal-Wallis tests. For P. pouchetii, we observed a significant increase in qPCR ratios over time in the Control (Table 3), while qPCR ratios in the NP and NPSi mesocosm treatments, in which $P$. pouchetii blooms occurred near the end of the experimental period, decreased significantly across the experimental period. qPCR ratios also decreased significantly over time in Raunefjorden samples (Fig. 4A, Table 3). Kruskal-Wallis tests of $S$. marinoi qPCR ratios, in contrast, identified significant increases over time in the Control, NP and NPSi mesocosm treatments (Fig. 4B, Table 3), while a significant decrease in $S$. marinoi qPCR ratios was observed in Raunefjorden samples (Fig. 4B and Table 3). The strongest temporal difference in $S$. marinoi qPCR ratios occurred between 21 March and 28 March in the NP $(p<0.0001)$ and NPSi $(p=0.00046)$ mesocosms. The increasing trend in $S$. marinoi qPCR ratios in mesocosms over time (Fig. 4B) was coincident with the decline of the $S$. marinoi bloom in these treatments (Fig. 3D-F). For Raunefjorden samples, higher $S$. marinoi ratios were observed during the first half of the experiment, but these dropped sharply after 21 March $(p=0.00616)$, coincident with an apparent recovery of $S$. marinoi populations in Raunefjorden at this time (Fig. 3D-F).

\section{DISCUSSION}

One of the main purposes of this study was to test whether relative grazing by Calanus on $P$. pouchetii changes in response to $P$. pouchetii bloom development in natural assemblages of phyto- and microplankton. Our qPCR results suggest that neither single-celled nor colonial $P$. pouchetii cells contributed significantly to Calanus diet, not even when P. pouchetii reached high abundances at the end of the experiment. As a consequence of incomplete P. pou- 


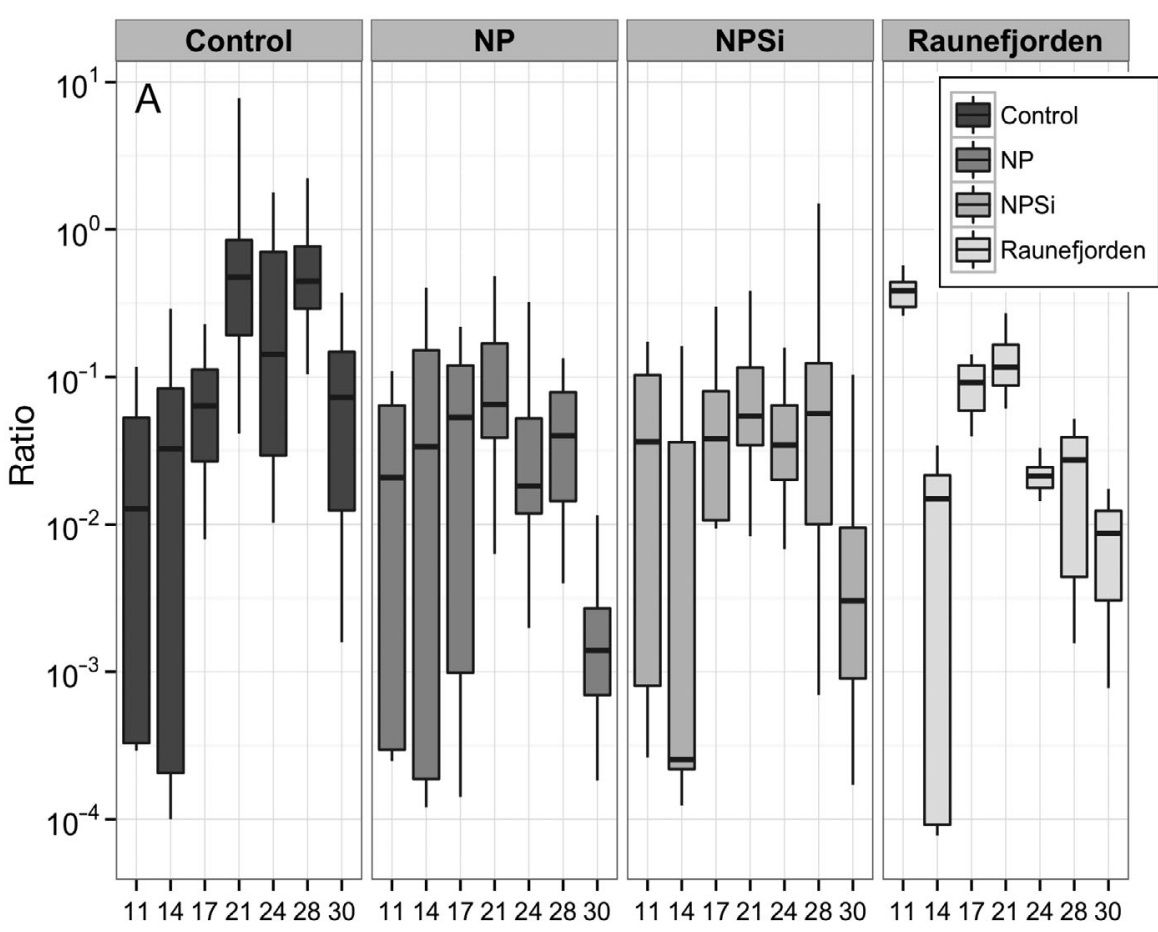

Date in March 2012

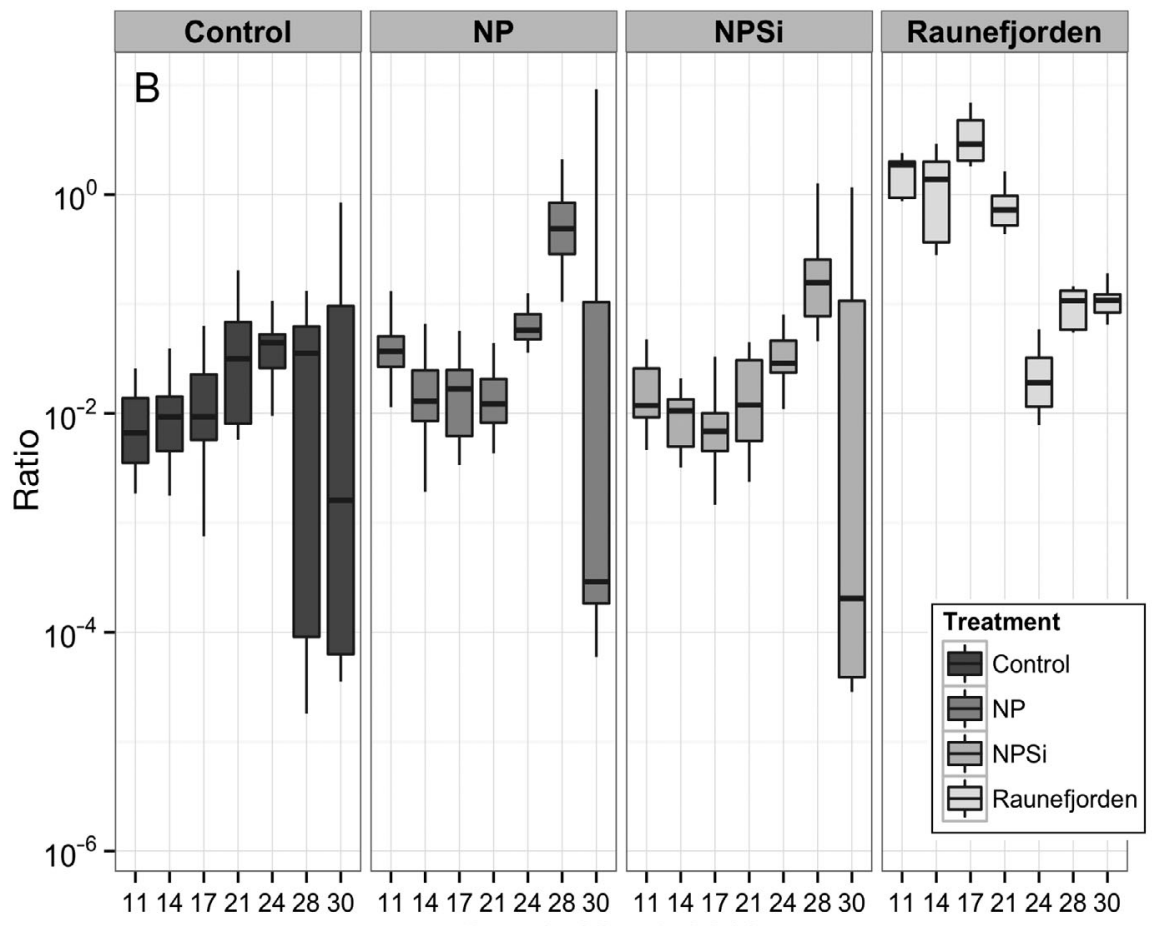

Date in March 2012

Fig. 4. Box-and-whisker plots showing qPCR target gene copy number ratios for (A) Phaeocystis pouchetii or (B) Skeletonema marinoi in the gut content of copepods (copies copepod ${ }^{-1}$ ) relative to gene copy abundance in seawater (copies $\mathrm{ml}^{-1}$ ). Line: median; box: 25th-75th percentiles; whiskers: 5th-95th percentiles; outliers not shown for simplicity chetii bloom development, however, we were unable to assess the soundness of the hypothesis that colony formation by $P$. pouchetii serves to inhibit predation by Calanus copepods (Estep et al. 1990). Production of DMSP, acrylic acid and extracellular polysaccharides (Dutz et al. 2005 but see also Huntley et al. 1987, Kuhlisch \& Pohnert 2015) by Phaeocystis may have increased avoidance by copepods, however the influence of chemical factors on Calanus grazing has not been tested here.

Our grazing proxy also allowed us to identify an inverse relationship between $S$. marinoi bloom development and increased consumption of S. marinoi by Calanus toward the end of the experiment. This is similar to a report by (Barofsky et al. 2010), suggesting that dead or dying $S$. marinoi cells may be more bioavailable for Calanus. While inside mesocosm chambers, copepods had access to abundant and diverse prey organisms of potentially higher nutritional quality, including ciliates and dinoflagellates (Gifford \& Dagg 1988, Kleppel et al. 1991), allowing copepods to be selective in their choice of prey (e.g. Kleppel 1993, Kiørboe et al. 1996, Leising et al. 2005a, and references below). Although our qPCR ratios indicate that $S$. marinoi bloom declines were positively correlated with increased relative consumption by copepods (Fig. 4B), there is also the possibility that $S$. marinoi in mesocosm decreased due to grazing by microzooplankton. We also observed an increase in the dinoflagellate Gyrodinium spirale in all mesocosm treatments (Control, NP and NPSi) over the course of the experiment (Fig. S3B in the Supplement), which may offer an alternative explanation for the decline in abundance of $S$. marinoi in mesocosm treatments after 24 March (Fig. 3E-G). This heterotrophic dinoflagellate is specialized in grazing on chain-forming 
Table 3. Influence of sampling date on qPCR ratios for each treatment as determined by Kruskal-Wallis pairwise comparisons using Tukey and Kramer (Nemenyi) posthoc tests for independent interactions. Significant results $(\alpha=0.05)$ are in bold

\begin{tabular}{|c|c|c|c|c|c|c|c|c|c|c|c|c|}
\hline \multirow{2}{*}{$\begin{array}{l}\text { Date } \\
\text { March }\end{array}$} & \multicolumn{6}{|c|}{ Phaeocystis pouchetii } & \multicolumn{6}{|c|}{ - Skeletonema marinoi } \\
\hline & 11 & 14 & 17 & 21 & 24 & 28 & 11 & 14 & 17 & 21 & 24 & 28 \\
\hline \multicolumn{13}{|c|}{ Control } \\
\hline 14 & 0.99891 & - & - & - & - & - & 0.9881 & - & - & - & - & - \\
\hline 17 & 0.65156 & 0.85839 & - & - & - & - & 0.9343 & 0.9999 & - & - & - & - \\
\hline 21 & $1.9 \mathrm{e}-09$ & $1.7 e-10$ & $1.8 \mathrm{e}-06$ & - & - & - & 0.0158 & 0.0654 & 0.1581 & - & - & - \\
\hline 24 & 0.00098 & 0.00120 & 0.11654 & 0.08597 & - & - & 0.0016 & 0.0073 & 0.0214 & 0.9569 & - & - \\
\hline 28 & $9.8 e-09$ & $2.0 e-09$ & $7.2 \mathrm{e}-06$ & 1.00000 & 0.10809 & - & 0.3669 & 0.7402 & 0.8964 & 0.9438 & 0.5110 & - \\
\hline 30 & 0.58030 & 0.80523 & 1.00000 & $1.1 \mathrm{e}-07$ & 0.07118 & $8.7 e-07$ & 0.7050 & 0.9647 & 0.9957 & 0.6797 & 0.2132 & 0.9987 \\
\hline \multicolumn{13}{|l|}{ NP } \\
\hline 14 & 0.99398 & - & - & - & - & - & 0.22246 & - & - & - & - & - \\
\hline 17 & 0.63640 & 0.92447 & - & - & - & - & 0.22893 & 1.00000 & - & - & - & - \\
\hline 21 & 0.00125 & 0.00341 & 0.17395 & - & - & - & 0.11162 & 0.99988 & 0.99984 & - & - & - \\
\hline 24 & 0.78260 & 0.98629 & 0.99889 & 0.00540 & - & - & 0.89058 & 0.00137 & 0.00146 & 0.00032 & - & - \\
\hline 28 & 0.23643 & 0.54609 & 0.99861 & 0.20741 & 0.87673 & - & 0.09237 & $3.0 \mathrm{e}-07$ & $3.3 e-07$ & $4.0 \mathrm{e}-08$ & 0.62121 & - \\
\hline 30 & 0.07345 & 0.00076 & $1.4 \mathrm{e}-06$ & $5.2 \mathrm{e}-14$ & $4.0 \mathrm{e}-08$ & $8.9 e-12$ & 0.04490 & 0.99171 & 0.99069 & 0.99978 & $5.6 e-05$ & $3.6 e-09$ \\
\hline \multicolumn{13}{|c|}{ NPSi } \\
\hline 14 & 0.09001 & - & - & - & - & - & 0.75565 & - & - & - & - & - \\
\hline 17 & 1.00000 & 0.02709 & - & - & - & - & 0.61331 & 0.99998 & - & - & - & - \\
\hline 21 & 0.37904 & $7.4 e-08$ & 0.26161 & - & - & - & 0.99951 & 0.90360 & 0.78935 & - & - & - \\
\hline 24 & 0.99384 & 0.00033 & 0.99411 & 0.44680 & - & - & 0.41407 & 0.00190 & 0.00068 & 0.09356 & - & - \\
\hline 28 & 0.89623 & $1.9 e-05$ & 0.86585 & 0.88754 & 0.99060 & - & 0.01406 & $1.3 \mathrm{e}-06$ & $3.3 e-07$ & 0.00046 & 0.73766 & - \\
\hline 30 & 0.03163 & 1.00000 & 0.00417 & $6.3 e-12$ & $1.9 \mathrm{e}-06$ & $2.6 e-08$ & 0.99995 & 0.83578 & 0.69356 & 1.00000 & 0.13864 & 0.00092 \\
\hline \multicolumn{13}{|c|}{ Raunefjorden } \\
\hline 14 & $1.8 \mathrm{e}-05$ & - & - & - & - & - & 0.99969 & - & - & - & - & - \\
\hline 17 & 0.81772 & 0.00698 & - & - & - & - & 0.91853 & 0.72662 & - & - & - & - \\
\hline 21 & 0.79047 & 0.00040 & 1.00000 & - & - & - & 0.90543 & 0.98763 & 0.24299 & - & - & - \\
\hline 24 & 0.00045 & 0.77719 & 0.10917 & 0.00999 & - & - & $4.0 e-05$ & 0.00026 & 8.1e-08 & 0.00616 & - & - \\
\hline 28 & 0.00020 & 0.86795 & 0.06817 & 0.00449 & 0.99999 & - & 0.01585 & 0.05439 & 0.00017 & 0.32475 & 0.77995 & - \\
\hline 30 & $6.4 e-09$ & 0.99649 & $5.0 \mathrm{e}-05$ & $4.9 e-08$ & 0.15258 & 0.24486 & 0.02411 & 0.07753 & 0.00031 & 0.40256 & 0.70245 & 1.00000 \\
\hline
\end{tabular}

diatoms such as $S$. marinoi (Stelfox-Widdicombe et al. 2004, Sherr \& Sherr 2007).

According to both models and empirical data, mesozooplankton such as Calanus are more likely to graze on ciliates and large diatoms than on microalgae such as $P$. pouchetii (Nejstgaard et al. 1997, 2001, Irigoien et al. 2005, Thingstad et al. 2008). Protistan microzooplankton comprise a significant fraction of mesozooplankton diet (Stoecker \& Capuzzo 1990), and in certain cases can be preferred prey species as assessed by clearance rate measurements in the laboratory (Hansen 1995, Gasparini et al. 2000) and in field studies (Kleppel et al. 1991, Leising et al. 2005b, Huo et al. 2008). This may in part be due to the higher nutritional value of microzooplankton (reviewed in Stoecker \& Capuzzo 1990, but see Koski et al. 2005, Huo et al. 2008) and/or to greater conspicuousness of ciliates caused by their larger size and higher motility (Jakobsen et al. 2005) relative to
Phaeocystis cells (Klein Breteler \& Koski 2003, Koski et al. 2005 and references therein). Indeed, ciliates were present in all mesocosm treatments over the experimental period (Fig. S3A). The spike in ciliate abundance in Raunefjorden on 12 March in combination with qPCR ratios showing Calanus grazing on $P$. pouchetii after 15 March indicate that Calanus may have consumed ciliates rather than $P$. pouchetii from 12-14 March. Once ciliates were grazed down to low abundances observed on 15 March, Calanus consumed $P$. pouchetii (Jonsson \& Tiselius 1990), albeit at low levels (Fig. 3C).

In some copepod samples we were unable to detect $P$. pouchetii or $S$. marinoi. We believe the most probable explanation for the lack of qPCR signals is genuinely low rates of ingestion of $P$. pouchetii or $S$. marinoi, as discussed above. We cannot, however, rule out temporal variability in copepod grazing, or technical factors associated 
with prey detection. The sensitivity of the TaqMan assays used in this study (linear detection as low as 100 target gene copies) suggest that even a very few cells should be detectable given the multi-copy nature of the target SSU rRNA genes. Alternatively, copepod digestion rates might have changed across the course of the experiment, altering prey detectability independent of actual ingestion rates (Mayzaud \& Razouls 1992). Since copepods were allowed $24 \mathrm{~h}$ to acclimate to the mesocosm environment prior to sampling, we find no reason to believe this to be the case in our experiment. Prey DNA degradation in the copepod gut was not corrected for in this study (Simonelli et al. 2009, Troedsson et al. 2009), and little is known about the relative rates of digestion of different phytoplankton prey particles after ingestion by predators. The silicate frustule of $S$. marinoi may protect it from rapid digestion during gut passage (Peterson \& Jones 2003) in copepods, while $P$. pouchetii cells possess no hard external structures and may therefore be digested at a faster rate. One comparative study of digestion rates, assessed as rate of visual disappearance, of whole ciliates and dinoflagellate cells fed to the ctenophore Mnemiopsis leidyi showed that naked ciliate and dinoflagellate taxa were digested much faster than loricate or thecate taxa (Sullivan 2010). However, Troedsson et al. (2009) demonstrated qPCR detection of a $74 \mathrm{bp}$ prey DNA fragment up to $30 \mathrm{~min}$ after prey consumption by Calanus copepods in the laboratory, suggesting that cellular lysis of prey in the predator gut is temporally uncoupled from prey DNA degradation.

We chose to use copepod chambers, rather than direct collection, for incubation and recovery of Calanus copepods in mesocosms (or Raunefjorden) prior to gut content analysis by qPCR, mainly because such net sampling intensity in the mesocosms would have jeopardized the entire experiment. The size of the mesh $(500 \mu \mathrm{m})$ covering the openings of the chambers was chosen as the best trade-off between the free passage of the natural diversity of prey organisms through copepod chambers and our ability to safely contain and recover Calanus copepods. Undamaged and active Calanus individuals were exclusively chosen for chamber incubations, and full gut content was visually assessed during sorting upon copepod recovery from chambers (P. Simonelli pers. obs.), allaying concerns that copepods were not feeding during the incubation period. The low and zero qPCR results for $P$. pouchetii and $S$. marinoi in copepod samples thus likely represent genuinely low rates of ingestion of these prey organisms. However, the large size of $P$. pouchetii colonies (up to several millimeters in diameter) in the NP and NPSi mesocosms on the last sampling day of the experiment (30 March) may have prevented passage through the plastic mesh, making $P$. pouchetii and possibly $S$. marinoi less available as food particles. Due to the potential technical bias associated with the 30 March samples, qPCR results for the NP and NPSi treatments on this date should be interpreted with caution. Full assessment of Calanus feeding selection and prey preference during $P$. pouchetii or $S$. marinoi blooms would require information about all prey particles ingested, however this falls outside the scope of this study.

Our qPCR ratio results are based on the implicit assumption that only primary predation of intact organisms was detected. Secondary predation, i.e. detection of $P$. pouchetii or $S$. marinoi in the gut content of organisms secondarily consumed by Calanus copepods, cannot be distinguished from direct predation using the qPCR method reported here due the high sensitivity of PCR (Harwood et al. 2001). It is therefore possible that the qPCR signals for $P$. pouchetii or $S$. marinoi generated from copepod samples were the result of copepod consumption of microzooplankton, e.g. dinoflagellates or ciliates, that had recently consumed these phytoplankton (see above). Controlled studies of the PCR-detectability of secondary predation in aphid-spidercarabid trophic chains, however, indicate that this trophic pathway generates only weak signals of short duration (Harwood et al. 2001, Sheppard et al. 2005). Furthermore, indirect consumption of naked environmental DNA (eDNA) from $P$. pouchetii or $S$. marinoi by mesocosm-incubated copepods was not controlled for in this experiment. As eDNA likely exists in the dissolved state in seawater and can be rapidly hydrolyzed by marine prokaryotes (Paul et al. 1987), its consumption by particle-feeding Calanus is unlikely. The seawater samples filtered for qPCR quantification of $P$. pouchetii and $S$. marinoi were not pre-treated with DNAse enzyme to remove eDNA prior to DNA extraction, however the filters utilized for seawater filtration have low binding efficiency for biomolecules including DNA (Pall Corporation, product information). We are therefore confident that the qPCR signals from copepod consumption or from seawater filtration have not been significantly affected by the presence of eDNA in mesocosms or in Raunefjorden.

qPCR results for $P$. pouchetii and $S$. marinoi in copepod samples, and hence qPCR ratios, are based 
on pools of 5 Calanus copepod individuals per sample. We chose to use pools of individuals in order to increase the probability of qPCR signal detection in the event of low copepod feeding rates on targeted phytoplankton (Nejstgaard et al. 2008). We are aware that variability in grazing between copepod individuals may be misrepresented in pooled samples, however our analysis consisted of 3 replicate pools of 5 copepods per mesocosm per sampling day. The high spread in qPCR signals from replicate copepod samples (Fig. 3A for P. pouchetii, Fig. 3D for S. marinoi) nevertheless identified clear trends in relative grazing by copepods, and in addition underscores the importance of replication in analysis of copepod diet using molecular analysis.

In spite of some methodological challenges addressed above, we have been able to show that the use of taxon-specific qPCR ratios to trace relative grazing by copepods on mixed assemblages of microbial eukaryotes dominated by either $P$. pouchetii or $S$. marinoi is an informative tool for studying mesozooplankton grazing. Furthermore, our results provide support for previous studies suggesting that Calanus copepods exhibit grazing selectivity that is de-coupled from specific prey density and likely based on nutritional content or chemical composition of prey. The complete biological impact of decoupling prey selection from prey abundance driven by life history (bloom development) is complex. However, given that the relative importance (in terms of abundance) of major phytoplankton groups seems to be changing in favor of taxa with low bioavailability as a consequence of global climate change (Moran 2015), such processes may become increasingly important. Further investigation of the full range of copepod prey organisms using universal molecular methods is therefore necessary to increase our understanding of copepod feeding selection and the efficiency of the marine microbial food web.

Acknowledgments. This study was funded by the Research Council of Norway (RCN) research project 'A novel crossdisciplinary approach to solve an old enigma: the food-web transfer of the mass-blooming phytoplankter Phaeocystis pouchetii' (Phaeonigma, project number 204479/F20). Additional support was received from the European Research Council Advanced Grant ERC-AG-LS8 'Microbial Network Organisation' (MINOS, project number 250254), the RCN project 'Processes and players in Arctic marine pelagic food webs - biogeochemistry, environment and climate change' (MicroPolar, project number 225956/E10) and from the VELUX Foundation Grant \# VKR022608.

\section{LITERATURE CITED}

Barofsky A, Simonelli P, Vidoudez C, Troedsson C, Nejstgaard JC, Jakobsen HH, Pohnert G (2010) Growth phase of the diatom Skeletonema marinoi influences the metabolic profile of the cells and the selective feeding of the copepod Calanus spp. J Plankton Res 32:263-272

Calbet A, Sazhin AF, Nejstgaard JC, Berger SA and others (2014) Future climate scenarios for a coastal productive planktonic food web resulting in microplankton phenology changes and decreased trophic transfer efficiency. PLOS ONE 9:e94388

> Cleary AC, Durbin EG, Rynearson TA (2012) Krill feeding on sediment in the Gulf of Maine (North Atlantic). Mar Ecol Prog Ser 455:157-172

> Durbin EG, Casas MC, Rynearson TA, Smith DC (2008) Measurement of copepod predation on nauplii using qPCR of the cytochrome oxidase I gene. Mar Biol 153: 699-707

Durbin EG, Casas MC, Rynearson TA (2012) Copepod feeding and digestion rates using prey DNA and qPCR. J Plankton Res 34:72-82

Dutz J, Breteler WK, Kramer G (2005) Inhibition of copepod feeding by exudates and transparent exopolymer particles (TEP) derived from a Phaeocystis globosa dominated phytoplankton community. Harmful Algae 4:929-940

> Estep KW, Nejstgaard JC, Skjoldal HR, Rey F (1990) Predation by copepods upon natural populations of Phaeocystis pouchetii as a function of the physiological state of the prey. Mar Ecol Prog Ser 67:235-249

Fessenden L, Cowles TJ (1994) Copepod predation on phagotrophic ciliates in Oregon coastal waters. Mar Ecol Prog Ser 107:103-111

Frischer ME, Danforth JM, Tyner LC, Leverone JR, Marelli DC, Arnold WS, Blake NJ (2000) Development of an Argopecten-specific 18S rRNA targeted genetic probe. Mar Biotechnol 2:11-20

> Gasparini S, Daro MH, Antajan E, Tackx M, Rousseau V, Parent JY, Lancelot C (2000) Mesozooplankton grazing during the Phaeocystis globosa bloom in the southern bight of the North Sea. J Sea Res 43:345-356

Gibson UE, Heid CA, Williams PM (1996) A novel method for real time quantitative RT-PCR. Genome Res 6: 995-1001

Gifford DJ, Dagg MJ (1988) Feeding of the estuarine copepod Acartia tonsa Dana: carnivory vs. herbivory in natural microplankton assemblages. Bull Mar Sci 43:458-468

> Goncalves RJ, Kiørboe T (2015) Perceiving the algae: how feeding-current copepods detect their nonmotile prey. Limnol Oceanogr 60:1286-1297

> Hansen FC (1995) Trophic interactions between zooplankton and Phaeocystis cf. globosa. Helgol Meersunters 49: 283-293

> Hansen FC, Van Boekel WHM (1991) Grazing pressure of the calanoid copepod Temora longicornis on a Phaeocystis dominated spring bloom in a Dutch tidal inlet. Mar Ecol Prog Ser 78:123-129

Harwood JD, Phillips SW, Sunderland KD, Symondson WOC (2001) Secondary predation: quantification of food chain errors in an aphid-spider-carabid system using monoclonal antibodies. Mol Ecol 10:2049-2057

> Holm-Hansen O, Riemann B (1978) Chlorophyll a determination: improvements in methodology. Oikos 30:438-447 > Huntley M, Tande K, Eilertsen HC (1987) On the trophic fate 
of Phaeocystis pouchetii (Hariot). II. Grazing rates of Calanus hyperboreus (Krøyer) on diatoms and different size categories of Phaeocystis pouchetii. J Exp Mar Biol Ecol 110:197-212

Huo YZ, Wang SW, Sun S, Li CL, Liu MT (2008) Feeding and egg production of the planktonic copepod Calanus sinicus in spring and autumn in the Yellow Sea, China. J Plankton Res 30:723-734

Irigoien X, Flynn KJ, Harris RP (2005) Phytoplankton blooms: a 'loophole' in microzooplankton grazing impact? J Plankton Res 27:313-321

- Jacobsen A, Egge JK, Heimdal BR (1995) Effects of increased concentration of nitrate and phosphate during a springbloom experiment in mesocosm. J Exp Mar Biol Ecol 187:239-251

> Jakobsen HH, Tang KW (2002) Effects of protozoan grazing on colony formation in Phaeocystis globosa (Prymnesiophyceae) and the potential costs and benefits. Aquat Microb Ecol 27:261-273

Jakobsen HH, Halvorsen E, Hansen BW, Visser AW (2005) The effects of food concentrations on prey motility on feeding Acartia tonsa and Temora longicornis: the importance of feeding modes. J Plankton Res 27:775-785

> Jónasdóttir SH, Visser AW, Richardson K, Heath MR (2015) Seasonal copepod lipid pump promotes carbon sequestration in the deep North Atlantic. Proc Natl Acad Sci USA 112:12122-12126

Jonsson PR, Tiselius P (1990) Feeding behaviour, prey detection and capture efficiency of copepod Acartia tonsa feeding on planktonic ciliates. Mar Ecol Prog Ser 60: $35-44$

Kiørboe T, Nielsen TG (1994) Regulation of zooplankton biomass and produktion in a temperate coastal ecosystem. I. Copepods. Limnol Oceanogr 39:493-507

Kiørboe T, Visser AW (1999) Predation and prey perception in copepods due to hydromechanical signals. Mar Ecol Prog Ser 179:81-95

Kiørboe T, Saiz E, Viitasalo M (1996) Prey switching behaviour in the planktonic copepod Acartia tonsa. Mar Ecol Prog Ser 143:65-75

- Klein Breteler WCM, Koski M (2003) Development and grazing of Temora longicornis (Copepoda, Calanoida) nauplii during nutrient limited Phaeocystis globosa blooms in mesocosms. Hydrobiologia 491:185-192

Kleppel GS (1993) On the diets of calanoid copepods. Mar Ecol Prog Ser 99:183-195

Kleppel GS, Holliday DV, Pieper RE (1991) Trophic interactions between copepods and microplankton: a question about the role of diatoms. Limnol Oceanogr 36:172-178

Koski M, Dutz J, Breteler WK (2005) Selective grazing of Temora longicornis in different stages of a Phaeocystis globosa bloom - a mesocosm study. Harmful Algae 4: 915-927

> Kuhlisch C, Pohnert G (2015) Metabolomics in chemical ecology. Nat Prod Rep 32:937-955

> Leising AW, Horner R, Pierson JJ, Postel J, Halsband-Lenk C (2005a) The balance between microzooplankton grazing and phytoplankton growth in a highly productive estuarine fjord. Prog Oceanogr 67:366-383

> Leising AW, Pierson JJ, Halsband-Lenk C, Horner R, Postel J (2005b) Copepod grazing during spring blooms: can Pseudocalanus newmani induce trophic cascades? Prog Oceanogr 67:406-421

Mayzaud P, Razouls S (1992) Degradation of gut pigment during feeding by a subantarctic copepod: importance of feeding history and digestive acclimation. Limnol Oceanogr 37:393-404

Moran M A (2015) The global ocean microbiome. Science 350:aac8455

Nejstgaard JC, Gismervikz I, Solberg PT (1997) Feeding and reproduction by Calanus finmarchicus, and microzooplankton grazing during mesocosm blooms of diatoms and the coccolithophore Emiliania huxleyi. Mar Ecol Prog Ser 147:197-217

> Nejstgaard JC, Hygum BH, Naustvoll LJ, Båmstedt U (2001) Zooplankton growth, diet and reproductive success compared in simultaneous diatom- and flagellate-microzooplankton-dominated plankton blooms. Mar Ecol Prog Ser 221:77-91

Nejstgaard JC, Frischer ME, Verity PG, Anderson JT and others (2006) Plankton development and trophic transfer in seawater enclosures with nutrients and Phaeocystis pouchetii added. Mar Ecol Prog Ser 321:99-121

Nejstgaard JC, Tang KW, Steinke M, Dutz J, Koski M, Antajan E, Long JD (2007) Zooplankton grazing on Phaeocystis: a quantitative review and future challenges. Biogeochemistry 83:147-172

Nejstgaard JC, Frischer ME, Simonelli P, Troedsson C and others (2008) Quantitative PCR to estimate copepod feeding. Mar Biol 153:565-577

> Paul JH, Jeffrey WH, DeFlaun MF (1987) Dynamics of extracellular DNA in the marine environment. Appl Environ Microbiol 53:170-179

Peterson CG, Jones TL (2003) Diatom viability in insect fecal material: comparison between two species, Achnanthidium lanceolatum and Synedra ulna. Hydrobiology 501: 93-99

Pohlert T (2015) PMCMR: Calculate pairwise multiple comparisons of mean rank sums. $\mathrm{R}$ package version 1.1. https://CRAN.R-project.org/package=PMCMR

R Core Team (2015) R: a language and environment for statistical computing. R Foundation for Statistical Computing, Vienna. www.r-project.org

> Schoemann V, Becquevort S, Stefels J, Rousseau V, Lancelot C (2005) Phaeocystis blooms in the global ocean and their controlling mechanisms: a review. J Sea Res 53: 43-66

Sheppard SK, Bell J, Sunderland KD, Fenlon J, Skervin D, Symondson WOC (2005) Detection of secondary predation by PCR analyses of the gut contents of invertebrate generalist predators. Mol Ecol 14:4461-4468

Sherr EB, Sherr BF (2007) Heterotrophic dinoflagellates: a significant component of microzooplankton biomass and major grazers of diatoms in the sea. Mar Ecol Prog Ser 352:187-197

Simonelli P, Troedsson C, Nejstgaard JC, Zech K, Larsen JB, Frischer ME (2009) Evaluation of DNA extraction and handling procedures for PCR-based copepod feeding studies. J Plankton Res 31:1465-1474

Sommer F, Stibor H, Sommer U, Velimirov B (2000) Grazing by mesozooplankton from Kiel Bight, Baltic Sea, on different sized algae and natural seston size fractions. Mar Ecol Prog Ser 199:43-53

Stelfox-Widdicombe CE, Archer SD, Burkill PH, Stefels J (2004) Microzooplankton grazing in Phaeocystis and diatom-dominated waters in the southern North Sea in spring. J Sea Res 51:37-51

Stoecker DK, Capuzzo JM (1990) Predation on protozoa: its 
importance to zooplankton. J Plankton Res 12:891-908

Stoecker DK, Nejstgaard JC, Madhusoodhanan R, Pohnert F and others (2015) Underestimation of microzooplankton grazing in dilution experiments due to inhibition of phytoplankton growth. Limnol Oceanogr 60:1426-1438

Sullivan LJ (2010) Gut evacuation of larval Mnemiopsis leidyi A. Agassiz (Ctenophora, Lobata). J Plankton Res 32:69-74

Thingstad TF, Bellerby RGJ, Bratbak G, Børsheim KY and others (2008) Counterintuitive carbon-to-nutrient coupling in an Arctic pelagic ecosystem. Nature 455:387-390

Editorial responsibility: Edward Durbin, Narragansett, Rhode Island, USA
Troedsson C, Frischer ME, Nejstgaard JC, Thompson EM (2007) Molecular quantification of differential ingestion and particle trapping rates by the appendicularian Oikopleura dioica as a function of prey size and shape. Limnol Oceanogr 52:416-427

Troedsson C, Simonelli P, Nägele V, Nejstgaard JC, Frischer ME (2009) Quantification of copepod gut content by differential length amplification quantitative PCR (dlaqPCR). Mar Biol 156:253-259

Wickham H (2009) ggplot2: Elegant graphics for data analysis. Springer, New York, NY

Submitted: June 2, 2015; Accepted: November 17, 2015 Proofs received from author(s): January 11, 2016 